\title{
室内の輻射に関する二、三の問題
}

\section{§1. 室内の相互輻射の式}

\section{1 基礎式}

室内表面（室内物体の表面をも含む）上の二点を $S$, $S^{\prime}$ とする。 $S$ 点の輻射能 $E_{(S)}$ は

$$
E_{(S)}=\varepsilon_{(S)} C_{b}\left(T_{(S)} / 100\right)^{4}
$$

$S$ 点の直接輻射受熱量 $D_{(S)}$ は

$$
\begin{aligned}
& D_{(S)}=\int_{F} E_{\left(S^{\prime}\right)} e_{\left(S, S^{\prime}\right)} d F_{\left(S^{\prime}\right)} \\
& e_{\left(S, S^{\prime}\right)}=\cos \beta \cos \beta^{\prime} / \pi r^{2}\left(S, S^{\prime}\right)
\end{aligned}
$$

$S$ 点の間接輻射受熱量 $I_{(S)}$ は

$$
\begin{aligned}
I_{(S)} & =\int_{F}\left(1-\varepsilon_{\left(S^{\prime}\right)}\right) D_{\left(S^{\prime}\right)} e_{\left(S, S^{\prime}\right)} d F_{\left(S^{\prime}\right)} \\
& +\int_{F}\left(1-\varepsilon_{\left(S^{\prime}\right)}\right) I_{\left(S^{\prime}\right)} e_{\left(S, S^{\prime}\right)} d F_{\left(S^{\prime}\right)}
\end{aligned}
$$

$S$ 点の正味輻射熱收得量 $q_{(S)}\left(\mathrm{kcal} / \mathrm{m}^{2} \mathrm{~h}\right)$ は

$$
q_{(S)}=\varepsilon_{(S)} D_{(S)}+\varepsilon_{(S)} I_{(S)}-E_{(S)} .
$$

無限平行二平面、同心球、無限同心円筒に対しては上式 は正確に解くことができ、すでに知られた解式となる。

1.2 近似解污ける誤差と誤差を小にする方法

上述の諸式には各種の近似解法が考元られるが、間接 輻射受熱量 $I_{(S)}$ を省略するのも一つの近似解法である。 てれを $1 ， 2$ の表面温が等しく $T$ である無限平行二平 面の場合に適用すると、1の面の正味輻射熱收得量は

$$
q_{(S)}=\left(\varepsilon_{2}-1\right) \varepsilon_{1} C_{b}(T / 100)^{4}
$$

となる。両表面温が等しいから， $q_{(S)}=0$ となるべきで あるが 0 とはならない。(1.1) (1.4)式代近似解法を適 用すると一般にこの種の䛊差を生じる。

全表面温が $T_{c}$ で一様のときは、任意の点の正味輻射 熱收得量は 0 であるから、(1.1) 式の代りに、

$$
E_{(S)}=\varepsilon_{(S)} C_{b}\left\{\left(T_{(S)} / 100\right)^{4}-\left(T_{c} / 100\right)^{4}\right\}
$$

灰用いれ詒誤差は小となり、さらに $T_{c}$ 范

$$
\max T_{(S)} \geq T_{c} \geq \min T_{(S)}
$$

なるように定めれば、前述のような物理的に不合理な結 果は生ぜず、 $T_{c}$ を適当比選べば、無限平行二平面等の 正確解を求める過程や、各種の近似解法も簡明になる。 また $T_{1}, T_{2}$ の表面温を有する二面間の輻射熱伝達にお いて $T_{c}$ を $T_{1}$ または $T_{2}$ のいずれかと等しく選び、 間接輻射受熱量 $I_{(S)}$ を省略すれば、NuBelt $の$ 近似式と なる。

\section{§2. 人体に対する輻射の影響を計算する二つの方法}

人体表面の $S$ 点について考える。 $\boldsymbol{q}=S$ 点の正味輻射損失熱量 $\left(\mathrm{kcal} / \mathrm{m}^{2} \mathrm{~h}\right), \theta_{6}=$ 表面温,

\section{正会員前田敏男*}

$\theta_{a}=S$ 点の境界層外気温、 $\alpha_{c}=$ 対流熱伝達率、 $H=$ 人体 の着衣表面または露出部表面に向つて内部から伝導によ つて流れる熱流 $\left(\mathrm{kcal} / \mathrm{m}^{2} \mathrm{~h}\right)$ とすると表面の熱収支から $H=\alpha_{c}\left(\theta_{b}-\theta_{a}\right)+q$

2.1 局所的作用温度 (Local Operative Temperature) $\theta_{r}=$ 人体表面の $S$ 点江対する平均輻射温度、 $\alpha_{r}=$ 平 均輻射温度を用いた場合の輻射熱伝達率、とすると

$$
q=\alpha_{r}\left(\theta_{b}-\theta_{r}\right)
$$

$$
\begin{aligned}
& (2.1) \text { 式に代入して } \\
& H=\alpha_{c}\left(\theta_{b}-\theta_{a}\right)+\alpha_{r}\left(\theta_{b}-\theta_{r}\right)=\left(\alpha_{c}+\alpha_{r}\right)\left(\theta_{b}-\theta_{0}\right)
\end{aligned}
$$

として、的を求めれば、

$$
\theta_{0}=\left(\alpha_{c} \theta_{a}+\alpha_{r} \theta_{r}\right) /\left(\alpha_{c}+\alpha_{r}\right)
$$

$\theta_{0}$ はすでて知られているように、作用温度であるが、S 点に対するものであるから局所的作用温度というととに する。

2.2 局所的輻射空気温度 (Local Rad-Air Temperature)

$q_{a}=$ 周壁表面温が $\theta_{a}$ に等しい場合の人体表面 $S$ 点 の正味輻射熱損失量 $\left(\mathrm{kcal} / \mathrm{m}^{2} \mathrm{~h}\right), \alpha_{r}{ }^{\prime}=$ 同上の場合の輻 射熱伝達率 とすると

$$
q_{a}=\alpha_{r}^{\prime}\left(\theta_{b}-\theta_{a}\right)
$$

(2.1) 式に代入して

$$
\begin{aligned}
& H=\left(\alpha_{c}+\alpha_{r}^{\prime}\right)\left(\theta_{b}-\theta_{a}\right)-\left(q_{a}-q\right) \\
& \theta_{e}=\left(q_{a}-q\right) /\left(\alpha_{c}+\alpha_{r}^{\prime}\right)
\end{aligned}
$$

と置き

$$
\theta_{r a}=\theta_{a}+\theta_{e}
$$

として、(2.6) 式は、

$$
H=\left(\alpha_{c}+\alpha_{r}{ }^{\prime}\right)\left(\theta_{b}-\theta_{r a}\right)
$$

$\theta_{e}$ は輻射の等価温度であり、 $\theta_{r a}$ は Sol-Air Temperature と同じ性質のものである。 $S$ 点に対するものであ るから局所的輻射空気温度というととにする。

$$
\alpha_{r}{ }^{\prime} \fallingdotseq \alpha_{r} \text { とすれば、(2.3) と (2.9) 式汃ら } \theta_{r a} \fallingdotseq \theta_{0}
$$
となる。すなわち、平均輻射温度を用いて求められる局 所的作用温度と、輻射の等価温度を用いて導かれる局所 的輻射空気温度と法近似的任等しい。

$\theta_{0}$ と $\theta_{r a}$ についてそれぞれ人体表面上の平均值を求 めれば、平均作用温度(Mean Operative Temperature)、 平均輻射空気温度 (Mean Rad-Air Temperature) が得 られる。もちろん、こ礼らは近似的に等しいものであ る。 